\title{
Penambahan Rimpang Temulawak (Curcuma xanthorriza Roxb) dan Mineral Zink dalam Pakan untuk Menilai Performans, Organ Fisiologi, dan Gambaran Darah Ayam Broiler dalam Situasi Stress Panas
}

\section{The Addition of Temulawak Rhizome (Curcuma xanthorriza Roxb) and Mineral Zinc in Feed to Assess Performance, Organ Physiology, and Blood Images of Broiler Chickens in Heat Stress Situations}

\author{
H. Masti ${ }^{1}$, S. Nabila ${ }^{1}$, A. Lammin ${ }^{2}$, J. Junaidi ${ }^{2}$, dan T. D. Nova ${ }^{2 *}$ \\ ${ }^{1}$ Program Pascasarjana, Fakultas Peternakan, Universitas Andalas, Padang - Indonesia \\ ${ }^{2}$ Program Studi Peternakan, Fakultas Peternakan, Universitas Andalas, Padang - Indonesia \\ *Corresponding E-mail: tertia16unand@gmail.com \\ (Diterima: 17 Januari 2020; Disetujui: 7 Mei 2020)
}

\begin{abstract}
ABSTRAK
Penambahan rimpang temulawak (Curcuma xanthorriza Roxb) dan mineral zink dalam pakan terhadap performan, bobot organ fisiologi, persentase karkas, dan gambaran darah broiler dalam situasi panas. Pada studi ini digunakan ayam broiler CP 707 sejumlah 80 ekor, menggunakan metode eksprimen. Penambahan rimpang temulawak pada pakan basal dan mineral zink pada air minum, yaitu P0 (pakan basal tanpa temulawak dan zink), P1 (1\% rimpang temulawak dan $40 \mathrm{ppm}$ mineral zink), P2 (2\% rimpang temulawak dan $40 \mathrm{ppm}$ mineral zink), dan P3 (3\% rimpang temulawak dan $40 \mathrm{ppm}$ mineral zink). Peubah yang diukur performan (pertambahan bobot badan, kosumsi ransum, konversi ransum, dan kosumsi air minum), bobot organ fisiologi (bobot hati, tiroid, ginjal, dan limpa), karkas (bobot karkas, persentase karkas, dan lemak abdominal) serta gambaran darah (jumlah eritrosit, hemoglobin, dan nilai hematokrit). Analisa keragaman mengartikan bahwa penggunaan rimpang temulawak dalam pakan dan mineral zink melalui air minum menunjukkan tidak berpengaruh nyata $(\mathrm{P}>0,05)$ pada peubah. Kesimpulannya bahwa walaupun ayam broiler dalam situasi panas akan dapat di atasi dengan penambahan rimpang temulawak dalam pakan basal dan pemberian mineral zink melalui air minum.
\end{abstract}

Kata kunci: broiler, temulawak, zink, panas, performan

\section{ABSTRACT}

The addition of temulawak rhizome (Curcuma xanthorriza Roxb) and zinc minerals in feed on performance, physiological organ weight, carcass percentage, and broiler's blood picture in hot situations. In this study, $80 \mathrm{CP} 707$ broiler chickens were used, using the expansion method. The adding ginger rhizome in basal feed and zinc minerals in drinking water; P0 (basal feed without ginger and zinc), P1 (1\% ginger rhizome and 40 ppm zinc mineral), P2 (2\% ginger rhizome and 40 ppm zinc mineral), and P3 (3\% ginger rhizome and 40 ppm zinc mineral). Variables measured by performance (body weight gain, feed consumption, feed conversion, and drinking water consumption), physiological organ weight (liver, thyroid, kidney, and spleen), carcass (carcass weight, carcass percentage, and abdominal fat) and depiction of physiological weight (weight of the liver, thyroid, kidney, and spleen), carcass (carcass weight, carcass percentage, and abdominal fat) as well as the depiction of physiological weight (liver weight, thyroid, kidney, and spleen), carcass (carcass weight, carcass percentage, and abdominal fat) blood (erythrocyte count, hemoglobin, and hematocrit value). Analysis of diversity means that the use of temulawak rhizomes in feed and zinc minerals through drinking water shows no significant effect $(P>0.05)$ on the variables. The conclusion was that although broiler chickens in a hot situation will be overcome by the addition of ginger rhizomes in basal feed and zinc mineral administration through drinking water.

Keywords: broiler, Curcuma, zink, heat stress, performance 


\section{PENDAHULUAN}

Pertambahan penduduk Indonesia berkembang cepat pada saat ini dan di ikuti dengan bertambahnya kebutuhan akan kosumsi sumber pangan hewani. Sumber pakan hewani yaitu dari bidang peternakan salah satunya dihasilkan oleh perunggasan. Di Indonesia, industri perunggasan merupakan penyumbang sumber pangan hewani yang di sukai dan diminati masyarakat terutama daging dari ayam broiler.

Ayam broiler merupakan jenis ayam yang sudah mengalami seleksi genetik di tujukan untuk memproduksi daging. Masalah yang ditemui pada saat usaha beternak ayam broiler adalah suhu lingkungan yang tinggi di daerah tropis yang bisa mencapai $34^{\circ} \mathrm{C}$. Temperatur lingkungan udara tropis ini dapat memicu terjadinya ayam broiler berproduktivitas tidak sesuai dengan standar produksinya yang mana menurut Charles (2002) suhu yang sesuai untuk ayam broiler adalah $18-22^{\circ} \mathrm{C}$. Ini karena menurut Tamzil (2014) panas yang diterima oleh tubuh unggas tidak bisa dikeluarkan kelingkungan sekitar diakibatkan tubuh unggas tidak mempunyai kelenjar keringat. Tekanan fisiologis tubuh yang disebabkan oleh panas lingkungan karena ketidakmampuan unggas menstabilkan suhu tubuhnya dinamakan dengan heat stress.

Heat stress juga memicu terjadinya kerusakan sel jaringan pada organ tertentu, baik berupa degenerasi maupun nekrosis. Heat stress ini juga mengakibatkan terjadinya berkurangnya menyerapan unsur makanan dalam pakan menyebabkan berkurangnya system kekebalan tubuh akhirnya terjadilah produktifitas menjadi terganggu (Noerjanto, 2007). Heat stress ini diakibatkan pada suhu tinggi mengakibatkan pada pemeliharaan ayam broiler ayam akan makan sedikit yang akibat suhu panas terjadinya produksi berkurang mengakibatkan kerugian bagi peternak yang memelihara. Selain itu untuk pemeliharaan ayam broiler menurut Yousef (1985) dampak negatif terhadap kondisi fisiologis dan produktifitas ayam suhu lingkungan yang tinggi. Hasil penelitian Harlova et al. (2002) mendapatkan jumlah sel darah merah, sel darah putih, konsentrasi hemoglobin, dan nilai hematokrit darah ayam broiler umur 1 minggu menurun. Disebabkan ayam broiler berada pada situasi suhu panas siang hari 35$40^{\circ} \mathrm{C}$ dan malam hari $28-30^{\circ} \mathrm{C}$. Zhang et al. (2007) melaporkan bahwa sel darah merah $2,86 \mathrm{juta} / \mathrm{mm}^{3}$, hematokrit $36,49 \%$, dan hemoglobin $10,45 \mathrm{~g} / 100 \mathrm{ml}$ ayam broiler pada dataran tinggi (ketinggian tempat $2.900 \mathrm{mdpl}$ ) pada dataran rendah (ketinggian $100 \mathrm{mdpl}$ ) masing-masing sel darah merah 1,77 juta/ $\mathrm{mm}^{3}$, hematokrit 29,73\%, dan hemoglobin 9,49 g/100 ml. Berarti pada dataran rendah dengan suhu lebih tinggi dibandingkan dengan dataran tinggi menyebabkan menurunnya jumlah eritrosit, hematokrit, dan hemoglobin.

Penambahan temulawak (Curcuma xanthorrhiza Roxb) dan mineral zink dalam pakan basal dapat digunakan untuk ayam broiler dalam situasi suhu panas. Temulawak (Curcuma xanthoriza Roxb) yang memiliki zat aktif kurkumin dalam struktur kimianya memiliki gugus hidroksil yang mudah teroksidasi serta mampu mendonorkan hidrogen kepada radikal bebas yang kekurangan hidrogen dan elektron pada orbital terluarnya (Narayansswamy, 2004). Pemberian temulawak sebanyak $0,5 \%$ dalam makanan mampu meningkatkan fertilitas daya tetas telur dan performans ayam petelur menurut Nadia et al. (2008). Mekanisme inilah yang merupakan kerja dari antioksidan dalam menangkal keganasan radikal bebas. Menurut Kusnaidi et al. (2010) bahwa pemberian temulawak ditambahkan dalam pakan dapat menanggulangi ayam dalam situasi panas. Zink dalam bentuk mineral inorganik berfungsi meningkatkan respon imun dan performan ayam broiler, sadangkan ditambahkan dalam pakan juga dapat berperan dalam peningkatan daya tahan tubuh (Ali et al., 2003). Sedangkan Lai et al. (2010) menyebutkan bahwa level zink sebanyak 40 $\mathrm{ppm}(\mathrm{mg} / 1 \mathrm{~kg}$ ransum) dapat digunakan untuk mengatasi cekaman panas pada ayam broiler sampai umur 6 minggu. Zink yang digunakan 
adalah zink oksida.

Berdasarkan hal diatas dilakukan penelitian Penambahan rimpang temulawak dalam pakan dan mineral zink melalui air minum sebagai antioksidan diharapkan dapat menetralisir efek cekaman panas bagi ayam yang terpapar suhu udara panas.

\section{METODE}

Studi ini dilaksanakan di kandang percobaan milik UPT kampus Peternakan Limau Manis Padang dan Laboratoriun Fisiologi Ternak Fakultas Peternakan Universitas Andalas Padang.

Rimpang temulawak adalah jenis tanaman jamu yang umum digunakan sebagai bahanjamu. Rimpangtemulawakini dicobakan pada ternak ayam (tanpa temulawak $/ 0 \%, 1 \%$, $2 \%, 3 \%$ ) dalam pakan dan mineral zink 40 ppm dalam air minum terhadap respon ayam yang berada dalam kondisi suhu panas. Studi ini memakai ayam broiler DOC CP 707 satu kotak (100 ekor). Kandang berbentuk box berukuran $70 \times 70 \times 60 \mathrm{~cm}$ sejumlah 20 , tiap box berisikan 5 ekor ayam. Suhu kandang yang dipakai pada penelitian ini adalah $31-33^{\circ} \mathrm{C}$. Setiap box dilengkapi dengan tempat pakan dan tempat minum. Sebagai broder yang digunakan adalah lampu pijar 100 watt/box. Dilengkapi dengan alat timbangan kapasitas 2 kg. Dalam studi ini ransum disusun sendiri sesuai dengan susunan ransum yang ditentukan menurut kebutuhan ayam broiler. Metode eksperimen menggunakan Rancangan Acak Lengkap (RAL) dengan 4 perlakuan dan 5 kali ulangan yang tiap box/unit 5 ekor ayam broiler. Perlakuan pada penelitian ini adalah penambahan rimpang temulawak dalam pakan dan mineral zink didalam air minum.

\section{Peubah yand Diamati}

\section{Kosumsi pakan}

Setiap pakan yang dihabiskan dikumpulkan selama satu minggu dikurangi dengan sisa pakan yang terbuang termasuk pakan yang tersisa dalam tempat minum.

\section{Pertambahan Bobot Badan (PBB)}

$$
\text { PBB }(\text { gr })=\frac{\text { BB Akhir }- \text { BB awal }}{\text { Jumlah hari pemeliharaan }}
$$

\section{Konversi Ransum}

Merupakan hasil bagi antara pakan yang dihabiskan dibandingkan dengan berat badan yang dihasilkan menggunakan rumus:

Konversi Ransum $=\frac{\text { Konsumsi Ransum (g/ekor) }}{\text { PBB (g/ekor) }}$

\section{Konsumsi Minum}

Berdasarkan jumlah air yang diberikan dikurangi dengan air yang tersisa. Konsumsi air minum untuk ayam broiler berdasarkan umur dihitung menggunakan rumus:

Kosumsi air $=\frac{\text { Air yang diberikan }(\mathrm{ml})-\text { Air sisa(ml) }}{\text { Jumlah ayam (ekor) }}$

\section{Organ Fisiologi}

Organ fisiologi diambil pada saat setelah pemotongan ayam dan pencabutan bulu, diambil organ dalam berupa (hati, tiroid, ginjal, dan limpa) dan dilakukan penimbangan. Ditimbang berat bobot organ fisiologis dalam $\mathrm{mg} / 100 \mathrm{~g}$ bobot badan.

\section{Bobot Karkas}

Merupakan hasil penimbangan ayam setelah dipotong dibuang darah, bulu, kepala, kaki serta organ dalam kecuali paru-paru dan ginjal, dengan rumus:

Bobot Karkas $=$ Bobot Hidup $-($ darah, bulu, kepala, leher, kaki, serta jeroan)

\section{Persentase karkas}

Merupakan bobot karkas dibagi dengan Bobot hidup di kali 100\% dengan rumus:

Persentase karkas $=\frac{\text { Bobot Karkas }(\mathrm{g})}{\text { Bobot } \operatorname{Hidup}(\mathrm{g})}$ X $100 \%$

\section{Persentase Lemak Abdominal}

Lemak abdominal adalah lemak yang terletak disekitar gizzard/rempela dan usus mulai dari rongga perut sampai iscium disekitar fibriskus dan dipisahkan dari rongga abdominal dibagi dengan berat karkas. 
Persentase Lemak Abdominal $=$

$\frac{\text { Bobot Lemak Abdominal (g) }}{\text { Bobot Karkas (g) }}$ X $100 \%$

\section{Gambaran Darah}

Variabel yang diukur untuk gambaran darah menghiting jumlah eritrosit, kadar hemoglobin, dan nilai hematokrit darah pada ayam yang telah diambil setelah umur 5 minggu. Darah ayam diambil ada bagian vena axilaris dengan menggunakan spuit $1 \mathrm{cc}$. Setelah diambil, dimasukkan darah ke dalam tabung EDTA kemudian dimasukkan kedalam kotak yang telah diberisi es. Darah selanjutnya dibawa ke laboratorium untuk menghitung jumlah eritrosit, kadar hemoglobin, dan nilai hematokrit.

\section{HASIL DAN PEMBAHASAN}

\section{Performans Ayam yang Ditambahkan Rimpang Temulawak}

Konsumsi Ransum. Berdasarkan analisa keragaman bahwa penambahan rimpang temulawak setiap perlakuan pada studi berpengaruh tidak nyata $(\mathrm{P}>0,05)$ terhadap konsumsi ransum. Pada ayam broiler tampak bahwa perlakuan P4 terjadi kecenderungan penurunan konsumsi ransum pada pemberian kombinasi Temulawak dan mineral zink ( $\mathrm{ZnO}$ ) (Tabel 1), hal ini disebabkan karena adanya rasa pahit yang menyebabkan turunnya palatabilitas pada konsumsi ransum. Meskipun pemakaian kombinasi zink dapat menyebabkan turunnya kosumsi ransum. Hasil penelitian disokong oleh Murtidjo (1987) menyatakan kosumsi pakan ayam broiler berkisar antara $987 \mathrm{~g} /$ ekor/ minggu. Sesuai dengan Praditya (2010) ayam broiler yang berada pada kondisi temperatur yang lebih tinggi dari zona nyaman ayam dapat menurunkan konsumsi pakan. Hal ini dilakukan untuk menurunkan produksi panas di dalam tubuh ayam broiler. Pada penelitian ini, dengan pemberian cekaman panas tidak menurunkan konsumsi ransum ayam broiler dikarenakan ayam tidak menurun konsumsinya.

\section{Pertambahan Bobot Badan.}

Berdasarkan analisa keragaman diketahui penggunaan rimpang temulawak dan mineral zink menunjukkan tidak ada perbedaan setiap taraf pemberian rimpang temulawak $(\mathrm{P}>0,05)$ terhadap pertambahan bobot badan ayam broiler. Pertambahan bobot badan pada studi ini berkisar antara 406,31-453,78 g/minggu (Tabel 1). Sedangkan standar pertambahan bobot badan untuk ayam broiler berkisar antara $585 \mathrm{~g} /$ minggu. Berdasarkan studi ini menyimpulkan penambahan temulawak dan mineral zink $(\mathrm{ZnO})$ belum mampu memicu pertumbuhan dengan indikator pertambahan bobot badan per minggu pada broiler sampai umur 5 minggu. Hal ini disebabkan kosentrasi mineral zinc yang diberikan dalam kategori rendah dan tidak terjaminnya mineral zink dikonsumsi sama banyak. Menurut Rizal (2006), kebutuhan zink untuk unggas yaitu 60-80 ppm dalam ransum. Rasyaf (1994) menyatakan konsumsi pakan berhubungan erat dengan pertambahan bobot badan, jika konsumsi pakan terpenuhi maka ayam broiler akan bertambah bobot badannya dalam arti kata bahwa kosumsi pakan berhubungan positif dangan bertambahnya bobot badan. Penambahan rimpang temulawak sebagai antioksidan dan penangkal cekaman panas berkisar $31-33^{\circ} \mathrm{C}$ sudah mampu menangkal cekaman panas yang seharusnya menurunkan pertambahan bobot badan pada perlakuan $\mathrm{P} 1$, P2, dan P3 karena menurut Charles (2002), zona nyaman ayam broiler sebagai hewan subtropik mempunyai kisaran $18-22^{\circ} \mathrm{C}$, sedangkan kenaikan temperatur $3^{\circ} \mathrm{C}$ akan menyebabkan ternak unggas lebih banyak mengutamakan Panting (pernafasan yang cepat tapi dangkal lewat mulut), hal ini akan menyebabkan menurunkan BMR (Basal Metabolic Rate) $10 \%$, sehingga mengganggu pertumbuhan ayam diatas 2 minggu.

Pemakaian tambahan Temulawak sampai dengan $3 \%$ ternyata cenderung menurunkan pertambahan badan per minggu, hal ini disebabkan rasa pahit spesifik yang menyebabkan ayam mengurangi jumlah pakan yg dikonsumsi. Sedangkan pada penelitian 
Tabel 1. Pengaruh kosumsi, pertambahan bobot badan, konversi ransum dan kosumsi air broiler yang diberi perlakuan Temulawak dan mineral zink $(\mathrm{ZnO})$

\begin{tabular}{lrrrr}
\hline \multirow{2}{*}{ Variable } & \multicolumn{4}{c}{ Perlakuan } \\
\cline { 2 - 5 } & \multicolumn{1}{c}{$\mathrm{A}$} & \multicolumn{1}{c}{$\mathrm{B}$} & \multicolumn{1}{c}{$\mathrm{C}$} \\
\hline Kosumsi ransum (g/ekor/minggu) & 803,03 & 803,17 & 805,29 & 770,18 \\
Pertambahan bobot badan (g/minggu) & 453,78 & 449,62 & 450,46 & 406,31 \\
Konversi ransum & 1,78 & 1,81 & 1,84 & 1,90 \\
Kosumsi air (ml/minggu) & $1.337,00$ & $1.220,66$ & $1.286,10$ & $1.226,67$ \\
\hline
\end{tabular}

Keterangan: $\mathrm{A}=$ temulawak $0 \%$ dan mineral zink $0,04 \mathrm{ppm}$; $\mathrm{B}=$ temulawak $1 \%$ dan mineral zink 0,04 ppm; $\mathrm{C}=$ temulawak $2 \%$ dan mineral zink $0,04 \mathrm{ppm}$; dan $\mathrm{D}=$ temulawak $3 \%$ dan mineral zink $0,04 \mathrm{ppm}$

Kusnadi (2009) penambahan temulawak dalam ransum mampu menghadapi cekaman suhu panas.

Konversi Ransum. Hasil sidik ragam pemakaian kombinasi temulawak dan mineral zink $(\mathrm{ZnO})$ menunjukkan hasil yang berbeda tidak nyata $(\mathrm{P}>0,05)$ terhadap konversi pakan ayam broiler (Tabel 1). Hasil penelitian menunjukkan pemakaian temulawak dapat menghasikan Rataan Konversi ransum yang optimal $(1,83)$. Pengaruh penggunaan mineral Zinc $(\mathrm{ZnO})$ memiliki kemampuan sebagai imunostimulan, mineral zink yang digunakan berbentuk zink anorganik disini berperan dalam meningkatkan performans dan respon imun terhadap broiler (Ali et al., 2003) sehingga dalam studi ini, penggunaan kombinasi Temulawak dan mineral zink ( $\mathrm{ZnO})$ sampai dengan dosis 3\% dapat meningkatkan pertumbuhan yang optimal dan penggunaan ransum yang sepadan, meskipun berdasarkan analisa statistik belum menunjukkan perbedaan yang nyata. Konversi Ransum penelitian rata-rata 1,83 menandakan penggunaan ransum ayam broiler dengan pemberian Temulawak dan Mineral zink (ZnO) menghasilkan konversi kecil dari 2 yang artinya ayam broiler pada penelitian efisien dalam penggunaan ransum. Hal ini di dukung oleh (Kartasudjana dan Suprijatna, 2006) berpendapat jika angka konversi ransum yang kecil $(<2)$ berarti banyaknya pakan yang dikonsumsi untuk menghasilkan satu kilogram daging menjadi lebih efisien.

Pertumbuhan adalah suatu penambahan ukuran tubuh berupa perbanyakan sel (hiperplasia) dan pertumbuhan (hipertropi), untuk pertumbuhan ini digunakan protein sebagai kerangka karbon dan mineral $(\mathrm{Ca}=$ kalsium) yang terdapat dalam tubuh, aktivitas pertumbuhan tersebut membutuhkan energi (ATP) diperoleh dari ransum baik berasal dari karbohidrat dan protein pakan, guna perbanyakan sel dan jaringan tubuh (Wahju, 1997). Kartasudjana dan Suprijatna (2006) mengemukakan bahwa pertumbuhan pada broiler mulanya perlahan lahan (0-2 minggu) selanjutnya akan cepat (pertumbuhan eksponensial) hingga mencapai perkembangan maksimum pertumbuhan relatif konstan (nol) artinya ternak mencapai kestabilan dalam pertumbuhan. Maka dari itu, pada penelitian ini dilakukan pengukuran dan pengambilan data mulai pada minggu ketiga. Perhitungan konversi ransum dengan membagi antara konsumsi ransum tiap minggu dengan pertambahan bobot badan pada minggu itu, hal ini sesuai dengan pendapat Rasyaf (1994) yang mengemukakan konversi ransum merupakan jumlah pakan yang dikonsumsi dihitung dalam satu minggu dibandingkan dengan bertambah bobot badan, berarti dalam penelitian ini ayam makan dengan efisien.

Kosumsi Air Minum. Berdasarkan hasil sidik ragam diketahui bahwa penggunaan kombinasi temulawak dan mineral zink $(\mathrm{ZnO})$ tidak nyata berpengaruh $(\mathrm{P}>0,05)$ terhadap konsumsi air minum ayam broiler. Dalam studi ini, konsumsi air minum berkisar antara 1.220,66-1.337,00 ml/minggu, 
(Tabel 1) sedangkan nilai standar konsumsi air minum untuk ayam broiler sampai umur 5 minggu adalah $1.250 \mathrm{ml} / \mathrm{minggu}$ (National Research Council, 1994). Hasil penelitian ini menunjukkan bahwa pemakaian konsumsi air minum pada ayam broiler meningkat terutama pada semua perlakuan disebabkan karena cekaman panas (lingkungan kandang $31-33^{\circ} \mathrm{C}$ ), meskipun keadaan ini tidak selalu tercapai pada kondisi hujan yang berfluktuasi pada pagi, siang, dan malam hari. Konsumsi air minum selalu akan meningkat pada lingkungan kandang diatas zona nyaman ayam broiler (Charles, 2002). Hal ini untuk mengatasi cekaman panas sebagai usaha homeostasis yakni ayam berusaha menyamakan kondisi lingkungan eksternal dengan panas tubuh, berupa pendinginan. Hal ini menyebabkan meningkatnya konsumsi air minum. Pada penelitian ini hasil menunjukan rata-rata konsumsi air minum ayam broiler yang diberikan temulawak dan mineral zink sebanyak 40 ppm pada air minumnya yaitu $1.267,61 \mathrm{ml} / \mathrm{minggu}$, data ini menunjukan cenderung meningkat bila dibandingkan dengan nilai standar konsumsi air minum ayam broiler yang normal atau tidak dalam cekaman sebanyak $1.250 \mathrm{ml} /$ minggu. Konsumsi air minum ayam pedaging disebabkan oleh beberapa faktor, tidak hanya berdasarkan pada konsumsi ransum atau kandungan nutrisi ransum yang diberikan, tetapi juga sangat dipengaruhi oleh keadaan stres pada ayam.

Adaptasi yang dilakukan ayam broiler saat terjadi situasi panas selain mengurangi konsumsi pakan juga meningkatkan konsumsi air minum untuk mengurangi suhu tubuh. Air berperan erat dalam mekanisme kehidupan, sangat erat hubungannya dengan mekanisme termoregulator dan kemampuan untuk bertahan hidup pada temperatur lingkungan yang tinggi. Ayam pada masa produksi mengkonsumsi air minum sebanyak 150-200 $\mathrm{ml}$ setiap hari pada suhu normal (Gibson et al., 1998). Menurut Bell and Weaver (2002), ketika suhu lingkungan panas maka aliran darah lebih banyak pada organ pernafasan (panting) pada saat yang sama aliran darah pada organ pencernaan terjadi penurunan sehingga bisa mengganggu pencernaan dan metabolisme tubuh ayam. Dalam studi ini cahaya diberikan yang terus menerus selama 24 jam akan merangsang ayam untuk makan dan minum serta aktivitas lainnya. Ayam broiler adalah makhluk diurnal yang apabila menerima rangsangan cahaya pada malam hari akan memberikan kesempatan ayam broiler untuk makan dan minum. Namun dari hasil studi selama 5 minggu, dimana 3 minggu perlakuan belum memberikan pengaruh nyata terhadap konsumsi air minum dikarenakan kondisi hujan yang berfluktuasi pada pagi, siang, dan malam hari, sehingga panas kandang tidak mencapai suhu (31$33^{\circ} \mathrm{C}$ ) penyebab stres pada ayam.

\section{Pengaruh Perlakuan terhadap Persentase Karkas, Lemak Abdominal, dan Lemak Daging}

Karkas. Penambahan temulawak dan mineral zink dalam pakan sampai 3\% ke dalam ransum merespon tidak berbeda terhadap persentase karkas pada setiap perlakuan dalam studi ini. Kandungan minyak atsiri pada temulawak tidak mempengaruhi persentase karkas ayam broiler, akan tetapi mampu meningkatkan kekebalan tubuh atau sebagai antioksidan. Menurut penelitian yang dilakukan oleh Yunilas et al. (2005) yang mendapatkan bahwa tidak dapat pengaruh pemberian temulawak sampai level $4 \%$ terhadap karkas ayam broiler. Diperkirakan zat yang ada pada temulawak kurang berperan dalam pembentukan karkas ayam broiler dan selanjutnya diduga temulawak pada ramsum tidak rata terkomsumsi oleh broiler sehingga zat bioaktif yang terkandung dalam temulawak berupa zat bioaktif yang terkandung dalam temulawak berupa kurkumin belum mampu untuk meningkatkan persentase karkas ayam broiler. Selain itu, tidak berbeda yang nyatanya disebabkan karena penambahan mineral zink juga memberikan pengaruh yang tidak berbeda nyata terhadap bobot hidup ayam broiler artinya mineral zink juga belum mampu untuk meningkatkan persentase 
Tabel 2. Pengaruh persentase karkas, persentase lemak abdomen, dan lemak daging broiler yang diberi perlakuan Temulawak dan mineral zink ( $\mathrm{ZnO})(\%)$

\begin{tabular}{lcccc}
\hline \multirow{2}{*}{ Variable } & \multicolumn{4}{c}{ Perlakuan } \\
\cline { 2 - 5 } & $\mathrm{A}$ & $\mathrm{B}$ & $\mathrm{C}$ & $\mathrm{D}$ \\
\hline Karkas & 66,08 & 67,88 & 69,41 & 66,91 \\
Lemak abdominal & 1,73 & 1,71 & 1,67 & 1,69 \\
Lemak daging & 6,10 & 5,64 & 5,48 & 5,57 \\
\hline
\end{tabular}

Keterangan: $\mathrm{A}=$ temulawak $0 \%$ dan mineral zink $0,04 \mathrm{ppm} ; \mathrm{B}=$ temulawak $1 \%$ dan mineral zink 0,04 ppm; $\mathrm{C}=$ temulawak $2 \%$ dan mineral zink $0,04 \mathrm{ppm}$; dan $\mathrm{D}=$ temulawak $3 \%$ dan mineral zink $0,04 \mathrm{ppm}$

karkas ayam broiler namun hanya sebagai atioksidan yang mampu menetralisir radikal bebas. Menurut Pahlepi et al. (2015) bobot karkas sangat berhubungan erat dengan bobot hidup, jika bobot hidup ternak tinggi maka akan tinggi pula bobot karkas.

Dari hasil penelitian juga mendapatkan hasil yang tidak berbeda nyata terhadap bobot badan akhir ayam broiler yang mengalami cekaman panas. Menurut Subeki et al. (2012) bangsa, umur, jenis kelamin, pakan, kondisi fisik dan lemak abdominal merupakan faktor yang mempengaruhi persentase karkas. Selanjutnya Subeki et al. (2012) menambahkan jika lemak tinggi maka persentase karkas akan rendah sedangkan lemak dan jeroan merupakan hasil ikutan yang tidak dihitung dalam persentase karkas. Angka persentase karkas pada studi ini berkisar antara 66,08-69,41(Tabel 2). Nilai ini menunjukkan persentase karkas yang normal, sesuai dengan pendapat Pesti and Bakalli (1997) yang menyatakan bahwa bobot karkas ayam umur lima minggu berkisar antara $60,52-69,91 \%$ dari bobot hidup. Hasil studi ini lebih rendah dari hasil penelitian Salam et al. (2013) ayam boriler diberi tepung jintan hitam (Nigella sativa) dalam ransum selama musim panas, bahwa persentase karkas bagian tubuh ayam broiler berkisar antara $65-$ $75 \%$ dari bobot hidup. Terjadinya perbedaan disebabkan karena perbedaan ransum atau bahan pakan penyusun ransum, sedangkan faktor lain juga mempengaruhi karkas broiler adalah bangsa, jenis kelamin, umur, berat badan, dan makanan.

Lemak Abdominal. Rata-rata persentase lemak abdominal broiler pada penelitian ini berkisar antara 1,67\%-1,73\% (Tabel 2). Berdasarkan hasil penelitian yang didapat masih dalam rentang normal. Menurut pendapat Becker et al. (1979), kandungan lemak abdominal berkisar 0,78-3,78\% (penelitiannya dilakukan pada ayam dewasa), begitu juga menurun Rose (1997) menyatakan bahwa lemak abdominal berjumlah sekitar $50 \%$ dari berat total lemak dalam rongga tubuh. Berdasarkan analisis keragaman menunjukkan bahwa perlakuan pemberian temulawak kedalam ransum dan pemberian mineral zink memberikan pengaruh tidak nyata $(\mathrm{P}>0,05)$ terhadap persentase lemak abdominal ayam broiler yang mengalami cekaman panas. Artinya pemberian temulawak sampai level 3\% belum membantu menekan kandungan lemak abdominal ayam broiler pada penelitian, dan penambahan mineral zink tidak memberikan pengaruh yang nyata atau menurunkan lemak abdominal pada broiler. Marwandana (2012) menyatakan tidak berpengaruhnya pakan yang dikonsumsi setiap perlakuan yang hampir sama pada studi ini, disebabkan perlakuan terhadap lemak abdominal menghasilkan angka yang hampir sama. Syzka et al. (2009) berpendapat bahwa jumlah total lemak abdomen dan penyebaran disetiap bagian-bagian tubuh ayam tergantung pakan yang dikonsumsinya. Setiawan dan Sujanan (2009) menambahkan bahwa pembentukan lemak pada ayam broiler 
Tabel 3. Pengaruh organ fisiologis bobot hati, tiroid, ginjal, dan limpa broiler yang diberi perlakuan Temulawak dan mineral zink $(\mathrm{ZnO})(\mathrm{mg} / 100 \mathrm{gBB})$

\begin{tabular}{lrrrr}
\hline \multirow{2}{*}{ Variable } & \multicolumn{4}{c}{ Perlakuan } \\
\cline { 2 - 5 } & \multicolumn{1}{c}{$\mathrm{A}$} & \multicolumn{1}{c}{$\mathrm{B}$} & \multicolumn{1}{c}{$\mathrm{C}$} \\
\hline Bobot hati & $2.266,62$ & $2.228,48$ & $2.043,77$ & $2.151,32$ \\
Bobot tiroid & 6,56 & 5,79 & 5,78 & 5,82 \\
Bobot ginjal & $1.165,05$ & $1.050,18$ & $1.074,49$ & $1.149,35$ \\
Bobot limpa & 135,95 & 122,98 & 140,18 & 127,43 \\
\hline
\end{tabular}

Keterangan: $\mathrm{A}=$ temulawak $0 \%$ dan mineral zink $0,04 \mathrm{ppm} ; \mathrm{B}=$ temulawak $1 \%$ dan mineral zink 0,04 ppm; $\mathrm{C}=$ temulawak $2 \%$ dan mineral zink $0,04 \mathrm{ppm}$; dan $\mathrm{D}=$ temulawak $3 \%$ dan mineral zink $0,04 \mathrm{ppm}$

meningkat pada umur lima minggu, sementara umur 21 sampai umur 33 hari relatif masih rendah yakni $1,40-3,19 \%$ dari bobot badan. Sedikitnya lemak abdomen disebabkan oleh zat makanan yang terserap ditujukkan untuk pertumbuhan badan ayam broiler.

Lemak Daging. Pada setiap perlakuan memberikan respon yang sama terhadap kadar lemak daging. Rataan kadar lemak daging hasil penelitian berkisar antara 5,48-6,10\% (Tabel 2). Hasil ini tidak jauh berbeda dengan studi Kucukyilmaz et al. (2012) yang memperoleh kadar lemak daging broiler memiliki ratarata $6,54 \%$. Hasil penelitin ini menunjukkan tidak berbeda nyata $(\mathrm{P}>0,05)$ terhadap kadar lemak. Tidak berbeda nyatanya penelitian ini diduga disebabkan karena energi metabolime pada ransum yang sama. Menurut Anggorodi (1995) terbentuknya lemak tubuh pada ayam broiler terjadi karena energi yang dikonsumsi adanya kelebihan. Selain itu pada penelitian ini menghasilkan lemak abdominal yang tidak berbeda nyata antar perlakuan, begitu pula dengan kadar lemak daging yang dihasilkan. Hal ini sesuai dengan pendapat Leclercq and Witehead (1998) disitasi Mahfudz et al. (2009) menyatakan bahwa ketika lemak abdominal meningkat maka lemak karkas juga akan meningkat lemak abdominal dan kadar lemak karkas mempunyai hubungan korelasi positif, begitu juga sebaliknya.

\section{Pengaruh Perlakuan Terhadap Bobot Organ Fisiologi}

Bobot Hati. Hasil yang diperoleh pada saat penelitian dengan perlakuan penambahan rimpang temulawak di dalam pakan ayam sampai level $3 \%$ dan mineral zink di dalam minum sebanyak $40 \mathrm{ppm}$ memperlihatkan berpengaruh tidak nyata $(\mathrm{P}>0,05)$ terhadap bobot hati ayam broiler. Perlakuan pemberian temulawak didalam pakan dan mineral zink ke dalam air minum ayam broiler yang mengalami cekaman panas tidak memberikan pengaruh nyata dikarenakan kombinasi temulawak dan zink mineral merupakan kombinasi saling mempekuat dalam melindungi tubuh ayam dalam situasi panas dan organ internal ayam sudah berkembang dengan baik pada awal kehidupan. Berdasarkan hasil studi maka diperolehlah kisaran 2.043,768-2.266,620 $\mathrm{mg} / 100 \mathrm{~g}$ BB atau setara dengan 2,0-2,2\% bobot badan, sesuai dengan yang dikemukakan Nickel et al. (1977) yang menyatakan bahwa persentase bobot hati normal ayam broiler $1-2,3 \%$ bobot badan. Hal ini menandakan bahwa bobot hati ayam broiler lebih besar pada suhu pemeliharaan dingin yang disebabkan oleh aktifitas organ hati lebih tinggi sehingga terjadi peningkatan bobot hati.

Bobot Tiroid. Hasil yang diperoleh pada saat penelitian dengan perlakuan pemberian temulawak di dalam pakan ayam sampai level $3 \%$ dan mineral zink di dalam minum sebanyak $40 \mathrm{ppm}$, memperlihatkan hasil tidak nyata berbeda $(\mathrm{P}>0,05)$ terhadap bobot tiroid ayam broiler. Tidak berpengaruhnya penambahan temulawak terhadap bobot tiroid dikarenakan kombinasi temulawak dan mineral zink menghasilkan 
akibat saling menguntungkan dan efek yang baik bagi tubuh ayam perlindungan pada ayam broiler terhadap cekaman panas selain itu waktu cekaman yang diberikan masih tergolong singkat. Pada hasil penelitian bobot tiroid perlakuan berkisar antara 5,76-6,75 $\mathrm{mg} / 100 \mathrm{gBB}$ atau setara dengan $0,005-0,006$ $\%$ bobot badan. Hasil penelitian ini sejalan dengan penelitian Delpabican (2014) dengan pemakaian vitamin $\mathrm{C}$, menyatakan bahwa pemberian CPO sampai level 3\% dan vitamin C 500 ppm ditambahkan kedalam pakan menghasilkan tidak ada pengaruhnya terhadap bobot tiroid ayam broiler dalam situasi panas sampai umur 6 minggu dengan kisaran bobot tiroid yaitu $6,32-6,52 \mathrm{mg} / 100 \mathrm{~g}$ bobot badan. Serta sejalan dengan pendapat Sturkie (1976) bahwa bobot organ tiroid unggas beratnya antara $0,004-0,007 \%$ berdasarkan bobot badan. Suhu lingkungan diatas zona nyaman $\left(29-33^{\circ} \mathrm{C}\right)$ yang dikhawatirkan dapat mengakibatkan stress yang pada kelanjutannya dapat menyebabkan fungsi tiroid terganggu ternyata dengan pemberian temulawak dalam ransum dan mineral zink dalam air minum berpengaruh tidak nyata terhadap bobot tiroid, ini menandakan bahwa kelenjar tiroid tidak terganggu. Penambahan temulawak dalam pakan dan mineral zing melalui air minum sama-sama berfungsi sebagai antioksidan yang saling melengkapi dan memperkuat dalam mengatasi efek dari cekaman panas, sehingga tidak mengganggu fungsi tiroid ayam broiler, sejalan dengan pendapat Narayanswamy et al. (2004) menyatakan dampak cekaman panas kurang pada ayam broiler akibat dari ekstrak tanaman obat anti stress melalui aktifitas antioksidan yang ditemui pada tanaman.

Bobot Ginjal. Hasil yang diperoleh pada saat penelitian dengan perlakuan pemberian temulawak di dalam pakan ayam sampai level $3 \%$ dan mineral zink di dalam minum sebanyak $40 \mathrm{ppm}$ menghasilkan tidak nyata berpengaruh $(\mathrm{P}>0,05)$ pada bobot ginjal ayam broiler (Tabel 3 ). Tidak berpengaruhnya pemberian pemberian perlakuan di duga karena waktu cekaman panas yang singkat.
Serta bobot ginjal tidak berpengaruh nyata dengan perlakuan disebabkan juga karena bobot hati tidak berpengaruh. Jika fungsi hati terganggu menyebabkan hasil metabolisme dihati yang dikeluarkan melalui ginjal akan bekerja lebih aktif. Menurut Tanudimadja (1974) mengemukakan bahwa ginjal akan menjadi besar sehingga fungsi hati terganggu, dan ditambahkan bahwa hasil metabolisme hati yang akan dikeluarkan ginjal, membuat ginjal bekerja lebih aktif yang akan membuat membesarnya ginjal. Fungsi ginjal utama memproduksi urine melalui proses filtrasi dan reabsorbsi beberapa nutrient dengan demikian ginjal memiliki peran dalam pengaturan keseimbangan cairan tubuh pada ayam. Sesuai dengan pendapat Frandson (1992) mengemukakan fungsi ginjal beraktivitas guna mempertahakan situasi yang relatif konstan dari lingkungan internal di dalam tubuh.

Bobot Limpa. Hasil analisa keragaman menunjukkan bahwa penambahan rimpang temulawak di dalam pakan ayam dan mineral zink di dalam minum ayam broiler dalam situasi lingkungan panas sampai level temulawak 3\% dan mineral zink sebanyak 40 ppm memberikan yang tidak nyata $(\mathrm{P}>0,5)$ terhadap bobot limpa ayam broiler. Tidak berpengaruh nyatanya kemungkinan disebabkan karena kombinasi temulawak dan mineral zink mengakibatkan kerja memperkuat satu sama lain dan mencakup dalam perlindungan pada ayam broiler dalam situasi panas serta waktu cekaman yang tergolong singkat. Rataan bobot limpa pada perlakuan berkisar antara 122,98$140,18 \mathrm{mg} / 100 \mathrm{gBB}$ atau setara dengan 1,2$1,4 \%$ bobot badan. Hasil tersebut sesuai dengan temuan Heckert et al. (2002) yang menunjukkan bahwa bobot limpa ayam broiler berkisar antara $88-156 \mathrm{mg} / 100 \mathrm{~g}$ bobot badan. Di tambahkan Kusnaidi dan Julardi (2010) bahwa pemberian stress pada ayam broiler menghasilkan pengaruh tidak nyata pada bobot limpa. Serta hasil penelitian Tonghyani et al. (2007) yang menyatakan bahwa pemberian choromium $500 \mathrm{pb}$ dan $1.500 \mathrm{ppb}$ 
Tabel 4. Pengaruh gambaran darah: jumlah eritrosit, haemoglobin, dan haematokrit broiler yang diberi perlakuan Temulawak dan mineral zink $(\mathrm{ZnO})$

\begin{tabular}{lcccc}
\hline \multirow{2}{*}{ Variable } & \multicolumn{4}{c}{ Perlakuan } \\
\cline { 2 - 5 } & $\mathrm{A}$ & $\mathrm{B}$ & $\mathrm{C}$ & $\mathrm{D}$ \\
\hline Jumlah eritrosit $\left(\mathrm{juta} / \mathrm{mm}^{3}\right)$ & 2,21 & 2,27 & 2,36 & 2,23 \\
Jumlah hemoglobin $(\mathrm{g} / 100 \mathrm{ml})$ & 8,20 & 9,26 & 9,88 & 8,22 \\
Jumlah hematokrit $(\%)$ & 27,00 & 28,00 & 28,60 & 27,20 \\
\hline
\end{tabular}

Keterangan: $\mathrm{A}=$ temulawak $0 \%$ dan mineral zink $0,04 \mathrm{ppm} ; \mathrm{B}=$ temulawak $1 \%$ dan mineral zink 0,04 ppm; $\mathrm{C}=$ temulawak $2 \%$ dan mineral zink $0,04 \mathrm{ppm}$; dan $\mathrm{D}=$ temulawak $3 \%$ dan mineral zink $0,04 \mathrm{ppm}$

pada ayam broiler yang mengalami stress panas tidak memberikan pengaruh terhadap organ limpa. Pada perlakuan P2 bobot limpa di dapatkan rata-rata $140,18 \mathrm{mg} / 100 \mathrm{gBB}$ yang menunjukkan pada perlakuan ini secara statistika rataan yang tertinggi. Penelitian ini sejalan dengan pendapat Rahmat et al. (2009) Pemberian kunyit sebanyak $0,2 \%$ terbukti dapat meningkatkan limpa pada ayam broiler yang mengalami stress panas.

\section{Pengaruh Perlakuan Terhadap Gambaran Darah}

Jumlah Eritrosit. Dari hasil analisis statistik, penambahan temulawak sampai 3\% berpengaruh tidak nyata $(\mathrm{P}>0,05)$ berdasarkan jumlah eritrosit ayam broiler. Menurut Charles (2002) suhu lingkungan yang cocok ayam broiler menjadi nyaman $18-22^{\circ} \mathrm{C}$. Nilai eritrosit kontrol yaitu perlakuan $\mathrm{P} 0$ cenderung lebih rendah daripada perlakuan $\mathrm{P} 1, \mathrm{P} 2$, dan P3, ini mengindikasikan perlakuan P0 pada situasi panas dengan turunnya jumlah eritrosit pada darah ayam, nilai perlakuan P0, P1, P2, P3 berturut-turut adalah $(2,21 ; 2,27 ; 2,36 ; 2,23$ juta/ $\mathrm{mm}^{3}$ (Tabel 4). Pada hasil penelitian jumlah eritrosit pada perlakuan P2 mendekati jumlah normal yaitu 2,33 juta/ $\mathrm{mm}^{3}$, sesuai dengan hasil penelitian Sugito (2007) bahwa jumlah eritrosit ayam dalam kondisi normal adalah $2,46 \mathrm{juta} / \mathrm{mm}^{3}$. Jumlah eritrosit diperdapat dalam kisaran pada perhitungan masih normal yaitu 2,21-2,36 juta/ $\mathrm{mm}^{3}$. Menurut Smith dan Mangkoewidjojo (1988) jumlah eritrosit pada ayam broiler normal berkisar antara 2,0-3,2 juta/ $\mathrm{mm}^{3}$. Walaupun perlakuan kontrol mengalami situasi panas masih belum memberikan pengaruh yang nyata terhadap jumlah eritrosit ayam broiler.

Perhitungan eritrosit tertinggi terjadi pada perlakun (P2) dan menurun saat perlakuan (P3), ini mengindikasikan pemberian temulawak diatas $2 \%$ menurunkan jumlah eritrosit pada ayam yang diberi temulawak dan mineral zink yang mengalami situasi panas oleh karena temulawak terdapat minyak atsiri dengan bau yang khas, dimana temulawak berasa pedas dan pahit mengurangi palatabilitas, tetapi belum memberikan efek yang nyata secara ststistik. Berdasarkan penyataan Harlova et al. (2002) yang menunjukkan bahwa situasi panas pada ayam nyata menurunkan jumlah sel darah merah, sel darah putih, konsentrasi hemoglobin, dan nilai hematokrit darah ayam broiler umur 1 minggu broiler (jika suhu siang hari $35-40^{\circ} \mathrm{C}$ dan suhu udara malam hari $28-$ $30^{\circ} \mathrm{C}$ ). Menurut Abbas (2009) suhu optimum untuk pertumbuhan ayam adalah $32-34^{\circ} \mathrm{C}$ saat berumur satu hari, dan turun $0,5^{\circ} \mathrm{C} /$ hari sampai $19^{\circ} \mathrm{C}$ pada umur 32 hari. Jumlah ratarata eritrosit yang cenderung meningkat dari perlakuan kontrol mengindikasikan temulawak berperan dalam mengatasi cekaman panas yang walaupun berpengaruh tidak nyata disebabkan oleh kandungan kurkumin dalam temulawak sebagai antioksidan untuk meredam radikal bebas. Hasil penelitian Wahyudi (2006) mengemukanan zat yang terdapat pada temulawak merupakan antioksidan adalah zat kurkumin. Ditambah lagi senyawa bahwa senyawa fenol mempunyai kemampuannya 
meniadakan radikal bebas dan radikal peroksida sehingga efektif dalam menghambat oksidasi lipida yang terdapat pada temulawak bisa berfungsi sebagai antioksidan (Nugraha, 2010). Pada penelitian ini (Tabel 4) juga tidak terlepas dari pengaruh fungsi zink yaitu sebagai anti oksidan untuk meredam radikal bebas, sesuai dengan pandapat Gropper et al. (2005) bahwa Zink berperan sebagai salah satu nutrisi antioksidan, yang berfungsi membuang radikal bebas pada plasma membran.

Jumlah Hemoglobin. Hasil analisis statistik menunjukkan bahwa penambahan temulawak dan mineral zink dalam pakan berpengaruh tidak nyata $(\mathrm{P}>0,05)$ terhadap kadar hemoglobin. Rendahnya kadar hemoglobin pada perlakuan kontrol P0 dari pada perlakuan $\mathrm{P} 1, \mathrm{P} 2$, dan $\mathrm{P} 3$ dapat terjadi karena tanpa temulawak $0 \%$ dan mineral zink dan P0 tidak diberikan anti cekaman kombinasi temulawak dan mineral zink. Suhu ayam saat penelitian $31-33^{\circ} \mathrm{C}$ sedangkan suhu nyaman bagi ayam broiler menurut Charles (2002) yakni $18-22^{\circ} \mathrm{C}$. Sesuai dengan pernyataan Kusnadi (2009) bahwa pemberian stress panas pada ayam broiler dapat menurunkan kandungan hemoglobin sebesar 20\%. Kadar hemoglobin ayam pada penambahan temulawak sampai 3\% dan mineral zink 40 ppm berkisar dalam batas normal yaitu: $8,06-$ $9,88 \mathrm{~g} / 100 \mathrm{ml}$ darah, sesuai dengan pendapat Jain (1993) bahwa kadar hemoglobin ayam broiler normal yaitu $7-13 \mathrm{~g} / 100 \mathrm{ml}$ darah. Menurut Hilman et al. (2000) situasi panas pada ayam bisa mengakibatkan tingkat $\mathrm{Hb}$ dan PCV menurun, menyebabkan berkurangnya intake okigen tubuh. Pada kelompok kontrol penambahan $0 \%$ temulawak dan mineral zink (P0) dan dikondisikan situasi panas terlihat bahwa kadar hemoglobin perlakuan P0 lebih rendah daripada perlakuan $\mathrm{P}$ 1, P2, dan $\mathrm{P} 3$ pada perlakuan $\mathrm{P} 3$ pemberian temulawak sebanyak $3 \%$ dalam ransum menurunkan kadar hemoglobin disebabkan karena rasa pahit pada temulawak sehingga konsumsi pakan ayam menurun (Tabel 4) dan menyebabkan anti cekaman tidak berjalan baik pada tubuh ayam, nilai hemoglobin cenderung meningkat tetapi belum memberikan efek yang nyata secara ststistik. Nilai Hemoglobin yang cenderung meningkat dari perlakuan kontrol mengindikasikan temulawak berperan dalam mengatasi cekaman panas yang walaupun berpengaruh tidak nyata disebabkan oleh kandungan kurkumin dalam temulawak sebagai antioksidan untuk meredam radikal bebas, sesuai dengan penelitian Wahyudi (2006) bahwa temulawak mengandung antioksidan alami dalam bentuk kurkumin dan senyawa fenol berfungsi sebagai antioksidan karena kemampuannya meniadakan radikal bebas dan radikal peroksida sehingga efektif dalam menghambat oksidasi (Nugraha, 2010).

Jumlah Hematokrit. Hasil analisis statistik menampilkan penambahan rimpang temulawak (Curcuma xanthorriza Roxb) dan mineral zink berpengaruh tidak nyata $(\mathrm{P}>0,05)$ pada persentase hematokrit (Tabel 4). Persentase hematokrit ayam broiler yang ditambahkan kombinasi temulawak dan mineral zink dalam pakan tidak berpengaruh nyata secara statistik disebabkan oleh suhu kandang yang masih dalam zona toleran terhadap ayam broiler yaitu suhu pada saat penelitiann adalah $31-33^{\circ} \mathrm{C}$. Nilai rata-rata hematokrit pada tabel terlihat cenderung meningkat hal ini membuktikan bahwa zat kurkuminyang terkandung didalam temulawak sudah memberikan efek antioksidan sehingga nilai hematokrit cenderung meningkat seiring dengan peningkatan jumlah eritrosit ayam broiler dalam situasi panas. Persentase hematokrit berada pada taraf normal. Sesuai dengan pendapat Jain (1993) bahwa persentase hematokrit ayam broiler normal adalah antara $22-35 \%$, dan diperkuan dengan penelitian Smith dan Mangkoewidjojo (1998) mengatakan taraf hematokrit normal pada ayam berkisar antara $24-43 \%$. Jika nilai hematokrit menurun maka pertumbuhan akan terganggu, jika persentase hematokrit meningkat, pertumbuhan ayam broiler juga akan terganggu karena meningkatnya persentase hematokrit ayam broiler menyebabkan visikositas darah meningkat (Siswani, 2006). Persentase hematokrit yang 
cenderung meningkat dari perlakuan kontrol mengindikasikan temulawak berperan dalam mengatasi cekaman panas yang walaupun berpengaruh tidak nyata disebabkan oleh kandungan kurkumin dalam temulawak sebagai antioksidan untuk meredam radikal bebas, sesuai dengan penelitian Wahyudi (2006) bahwa fenol dan kurkumin yang terdapat pada temulawak adalah antioksidan alami berfungsi sebagai antioksidan karena kemampuannya meniadakan radikal bebas dan radikal peroksida sehingga efektif dalam menghambat oksidasi lipida (Nugraha, 2010). Mineral zink juga mempengaruhi rata-rata presentase hematokrit yang didapat dalam penelitian ini. Menurut Piliang (2007) bahwa radikal bebas bisa dinetralisir oleh mineral zink yang berfungsi sebagai antioksidan sehingga proses kematian sel secara terencana dapat ditekan dan zink diperlukan untuk metabolisme protein, karbohidrat dan lemak, dan zink juga berperan dalam system kekebalan tubuh. Nilai hematokrit dipengaruhi oleh beberapa faktor antara lain spesies, umur, jenis kelamin, makanan, kesehatan ternak, dan faktor iklim (Swenson, 1993). Terjadinya level eritrosit meningkat memiliki pola yang sama dengan kandungan hematokrit karena persentase hematokrit tersebut merupakan kandungan sel darah merah berbanding volume total darah.

\section{KESIMPULAN}

Penambahan temulawak dan mineral zink dalam pakan ayam broiler sampai $3 \%$ tidak mempengaruhi performan, organ fisiologis, karkas, persentase karkas, lemak abdominal, lemak daging serta gambaran darah (jumlah eritrosit, hemoglobin, dan nilai hematokrit). Penambahan temulawak dan mineral zink dapat mentolerir ayam dalam situasi panas.

\section{DAFTAR PUSTAKA}

Abbas, M. H. 2009. Fisiologi Pertumbuhan
Ternak. Andalas University Press, Padang.

Anggorodi, R. 1995. Nutrisi Aneka Ternak Unggas. PT. Gramedia Pustaka. Jakarta.

Ali, S. A., Saye, M. A. M., El-eafa, and Abdallah, A. G. 2003. Performance and immune response of broiler chicks as affected by methionine and zinx or commercial zinc-methionine supplementations (abstrak). Egypt Poult Sci j :523 -540.

Becker W. A., J. V. Spencer., L. W. Minishand, and J. A. Werstate. 1979. Abdominal and carcas fat in five broiler strain. Poult. Sci. 60: 692-697.

Bell, D. D. and W. D. Weaver Jr. 2002. Commercial Chicken Meat and Egg Production. 5th Ed. Springer Science Business Media, Inc., New York.

Charles, D. R. 2002. Responses to the therminal environtment in: Environment Problem, A Guide to solution. Charles. D. A and A. W. Walker (Eds). Notingham, United Kingdom,pp. 1-16.

Delpabican, R. 2014. Pengaruh Kombinasi CPO (Crude Palm Oil) dan vitamin C (Asam Askorbat) dalam ransum sebagai anti stress terhadap organ fisiologi (Hati, Ginjal, dan Tiroid) ayam broiler yang mengalami cekaman panas. Skripsi. Fakultas Peternakan Universitas Andalas. Padang.

Frandson, R. D. 1992. Anatomi dan Fisiologi Ternak. Edisi ke -4. Terjemahan. Gadjah Mada University Press. Yogyakarta.

Gibson, S. W., P. Dun, and B. O. Hughes. 1998. The performance and behaviour of laying fowls in a covered strawyard system. Research and Development in Agriculture 5:153-163.

Gropper, S. S., J. L. Smith., J. L. and Groff. 2005. Advanced Nutrition and Human Metabolism. 4th Ed. Wardsworth, USA.

Harlova, H., J. Blaha., M. Koubkova., J. Draslarova, and A. Fucikova. 2002. Influence of Heat Stress on the Metabolic 
Response in broiler Chickens. Scientia Agriculturae Bohemica. 33: 145-149.

Heckert, R. A., I. Estevez., E. R. Cohen, and R. P. Riley. 2002. Effects of density and perch availability on the immune status of broilers. Poultry Sci. 81: 451-457.

Hillman, P. E., Scot, N. R. and Van Tienhoven, A. 2000. Physiological, responses and adaptations to hot and cold environments. in; Yousef, M. K, editor. Stress Physiology in Livestock. Volume 3, Poultry. Florida: CRC Pr. p: 1-71.

Jain, N. C. 1993. Essential of Veterinary Hematology. Philadelphia: Lea dan Febiger.

Kartasudjana, R. dan E. Suprijatna. 2006. Manajemen Ternak Unggas. Penebar Swadaya: Jakarta.

Kucukyilmaz, K. M., A. U. Bozkurt., E. N. Coth., M. Herken., Cunar, and E. Bintas. 2012. Chemical composition, fatty acid profile and colour of broiler meat as affected by organic and conventional rearing systems S. Afr. Journal Animal Science. 42(4): 360-368.

Kusnadi, E. 2009. Pengaruh berbagai cekaman terhadap perubahan beberapa komponen dan biokimia darah unggas. Seminar Nasional Teknologi Peternakan dan Veteriner. Fakultas Peternakan Universitas Andalas: Padang.

Kusnaidi., A. Djulardi, dan Rahmat. 2010. Peranan Temulawak (Curcuma xanthorriza Roxb) dalam memperbaiki Respon Ayam broiler (yang mengalami cekaman stres panas). Fakultas Peternakan: Universitas Padjajaran.

Lai, P. W., J. B. Liang., L. C. Hsia., T. C. loh, and Y. W. Ho. 2010. Effects of varying dietary zinc level and environmental temperatures on growth performance, feathering score and feathering score and feather mineral concentrations of broiler chicks. Asian-Aus. J. Anim.Sci. 23(7): 937-945.
Leclercq, B. and C. C. Whitehead. 1998. Leanes in Domestic Birds. Butterworth dan Co. Ltd-INDRA, London.

Mahfudz, L. D., Y. Ratnawati., E. Suprijatna, dan W. Sarengat. 2009. Performans karkas burung puyuh jantan akibat pemberian Limbah Distilasi Minuman Beralkohol (LDMB) dalam Ransum. Dalam: Prosiding Seminar Nasional Kebangkitan Peternakan. Fakultas Peternakan. Universitas Diponegoro. hal. 589-595.

Marwandana, Z. 2012. Efektivitas kombinasi jumlah dan bentuk ramuan herbal sebagai imbuan pakan terhadap peforma broiler. Skripsi. Fakultas Peternakan. Universitas Hasanuddin, Makasar.

Murtidjo, B. A. 1987. Pedoman Beternak Ayam broiler. Kanisius. Yogyakarta.

Narayanswamy, H. D., B. S. Kumar., V. G. Bhagwat., M. N. Dixit, and M. R. Nagaraja. 2004. Beneficial effects of geriforte (Vet Liquid) as an adaptogen in commercial broiler for summer stress. Line: 27-30.

Nadia, R., R. A. Hassan., E. M. Qota, and H. M. Fayek. 2008. Effect of Natural antioxidant on oxidative stability of eggs and productive and reproductive performance of laying hens. Internasional journal Poult. Sci. 7(2): 134-150.

Nickel, R., A. Schummer., E. Seiferle, W. G. Siller, and P. A. L. Weight. 1977. Anatom of the Domestic Bird. Verlag Paul Parey. Berlin.

Nugraha, A. A. 2010. Kajian kadar kurkuminoid total fenol dan aktivitas antioksidan oleoresin temulawak (Curcuma xanthorriza Roxb) dengan variasi teknik pengeringan dan warna kain penutup. (Skripsi) Fakultas Pertanian. Universitas Sebelas Maret.

Noerjanto, E. 2007. Ayam Heat stress, peternak stress. Trobos. Edisi November, Jakarta. 
Pahlepi, R., H. Hafid, dan A. Indi. 2015. Bobot akhir persentase karkas dan lemak abdominal ayam broiler dengan pemberian ekstrak daun sirih (Piper betle L.) dalam air minum. Jitro 4(1): 1-7.

Pesti, G. M. and R. I. Bakalli. 1997. Estimation of the compotition broiler carcass fo $\mathrm{m}$ their specific gravity. Poult.Sci. 76: 88101.

Piliang, W. G. 2007. Nutrisi Mineral. Program Pasca Sarjana Institut Pertanian Bogor: Bogor.

Praditya, K. J. 2010. Performa ayam broiler dalam kondisi kandang dengan suhu yang berbeda. Skiripsi. Institut Pertanian Bogor. Bogor.

Rahmat., A. Kusnaidi., E. dan Y. 2009. Laporan Penelitian Hibah Bersaing. Universitas Andalas, Padang.

Rasyaf. 1994. Makanan Ayam broiler Kanisius, Yogyakarta.

Rizal, Y. 2006. Ilmu Nutrisi Unggas. Andalas University Press, Padang.

Rose, S. P. 1997. Prinsiples of Poultry Sciences. Harper Adams Agricultural Collag. London.

Salam. S., A. Fatahilah., D. Sunarti, dan Isroli. 2013. Berat Karkas dan Lemak Abdominal Ayam broiler yang diberi Tepung Jintan Hitam (Nigella sativa) dalam Ransum selama Musim Panas. Sains Peternakan.11(2): 84-89.

Setiawan, I. dan Sujanan, E. 2009. Bobot Akhir, Persentase karkas dan lemak abdominal ayam broiler yang dipanen pada umur yang berbeda. Fakultas Peternakan. Universitas Padjajaran.

Siswani. 2006. Gambaran Darah Merah dan Pertumbuhan Mandalung yang Disuplementasi Vitamin C. Fakultas Kedokteran Hewan. Institut Pertanian Bogor: Bogor.

Smith, J. B. dan S, Mangkoewidjojo. 1998. Pemeliharaan, Pembiakan, dan Penggunaan Hewan Percobaan di
Daerah Tropis. Universitas Indonesia: Jakarta.

Sturkie, P. D. 1976. Avian Physiology. $2^{\text {nd }}$ Edition Spinger Verlag, New York.

Subeki, K., H. Abbas, dan K. A. Zura. 2012. Kualitas karkas (berat karkas, persentase karkas dan lemak abdomen) ayam broiler yang diberi kombinasi CPO (Crude Palm Oil) dan Vitamin C (Ascorbic Acid) dalam Ransum sebagai Anti Stress. Jurnal Peternakan.

Sugito. 2007. Kajian penggunaan kulit batang jaloh sebagai anti stress pada ayam broiler yang diberi cekaman. Disertasi. Program Pasca Sarjana, Institut Pertanian Bogor, Bogor.

Swenson, M. J. 1993. Physiologycal Properties and Celluler and Chemical Constituen of Blood in Dukes Physiology of Domestic Animal. 11rd Ed. Comstock Publishing Associates a Division of Cornell University Press, Ithaca and London.

Syzka, M. G., H. Supratman, dan Abun. 2009. Pengaruh imbangan energi dan protein ransum terhadap bobot karkas dan bobot lemak abdominal ayam ayam pedaging umur 3-5 minggu. J. Agroland 16(1): 105-112.

Tamzil, M. H. 2014. Stres Panas pada Unggas: Metabolisme, Akibat dan Upaya Penanggulangannya. 24(2): 57-66.

Tanudimadja, K. 1974. Anatomi veteriner VII. Anatomi dan Fisiologi Ayam. Fakultas Kedokteran Hewan Institut Pertanian Bogor, Bogor.

Tonghyani, M., Zarkesh, S., Shivazad, M. and Gheisari, A. 2007. Immune responses of broiler chicks fed chromium picolinate in heat stress condition. J. Poult. Sci. 44: 330-334.

Wahju, J. 1997. Ilmu Nutrisi Unggas, Cetakan ke 4. Gajah Mada University Press. Yogyakarta.

Wahyudi, A. 2006. Pengaruh penambahan kurkumin dari rimpang temugiring pada 
aktifitas antioksidan asam askorbat dengan metode FTR. Akta Kimindo. ITS. Surabaya. 2(1): 37-40.

Yunilas., E. Mirwandhono, dan O. Sinaga. 2005. Pengaruh Pemberiaan Tepung Temulawak (Curcuma Xanthorrizha Roxb) Dalam Ransum Terhadap Kualitas Karkas Ayam broiler Umur 6 Minggu. Jurnal Agribisnis
Peternakan. 1(2): 62-66.

Yousef, M. K. 1985. Stress Fhisiologi in Livestock . Poultry Vol 3. CRC Press Inc, Boca Raton, Florida pp. 70-75.

Zhang, H., C. X. Wu., Y. Chamba, and Y. Ling. 2007. Blood Characteristics for HighAltitude in Tibetan Chickens. Poult. Sci. 86: 1384-1389. 